\title{
Staying in the cities or returning home? An analysis of the rural-urban migration behavior in Vietnam
}

\author{
Loc Duc Nguyen ${ }^{1,2}$, Ulrike Grote ${ }^{1^{*}}$ (1) and Rasadhika Sharma ${ }^{1}$
}

* Correspondence:
grote@iuw.uni-hannover.de
${ }^{1}$ Institute for Environmental
Economics and World Trade, Leibniz
University Hannover Königsworther
Platz 1, 30167 Hannover, Germany
Full list of author information is
available at the end of the article

available at the end of the article

\begin{abstract}
This paper investigates the migration behavior of rural-urban migrants within Vietnam. It focuses on the length and intensity of migration and its respective determinants. The analysis uses panel data of 2200 rural households and data from a migrant tracking survey of 299 migrants from Vietnam. The findings show that migrants coming from rural households that faced a higher number of idiosyncratic shocks increase their stays in the cities, while those from households that experienced covariate shocks such as floods, droughts, or economic shocks shorten the lengths of their stays in the cities. An increased length of migration is also observed among migrants and households with higher human capital. Furthermore, a decreased income gap between rural and urban provinces due to the higher economic growth in the cities increases the duration of migration. With respect to the migration intensity, migrants intend to return sooner when they face shocks in the cities and the living conditions at their original places improve.
\end{abstract}

JEL Classification: D13, J28, J61, O15, O18, Z13

Keywords: Length of migration, Migration intensity, Random-effect Tobit regression, Vietnam

\section{Introduction}

Internal migration in emerging countries such as Vietnam has increasingly attracted the attention of scientists and policy-makers. Industrialization and urbanization create employment opportunities motivating labor to move out of the agricultural sector which is characterized by labor surplus problems. Thus, migration may influence the socioeconomic development of both departure and destination regions.

Decisions to migrate may simply reflect not only the goals or needs of the migrant but also the household's decision to maximize household income or minimize risks (Dercon 2002; Stark and Bloom 1985). Thus, migration is not only a coping strategy in response to shocks, including agricultural and economic shocks, but also a strategy for livelihood diversification of original households (Nguyen et al., 2015).

In the destination areas, migration strongly contributes to economic development by providing labor at low wage; however, it is also a source of several development problems. Due to the limitations of infrastructure in urban areas, migration exerts pressure on existing infrastructure and urban services such as housing, education,

(c) The Author(s). 2017 Open Access This article is distributed under the terms of the Creative Commons Attribution 4.0 International License (http://creativecommons.org/licenses/by/4.0/), which permits unrestricted use, distribution, and reproduction in any medium, provided you give appropriate credit to the original author(s) and the source, provide a link to the Creative Commons license, and indicate if changes were made. 
health care, water, sanitation, and transportation with numerous economic, social, and health consequences (UNFPA 2010). The government, both at the national and provincial levels, is concerned about overcrowding and poverty in major cities that tend to worsen because of migration from the countryside. There have also been concerns about migrants contributing to social disorder, including crime, drug, or vulnerability to HIV/AIDS (UNFPA 2010). Therefore, a household registration system is considered as an important tool to regulate the population movement, although this regulation may limit migrants' access to social protection programs, making them more vulnerable (Le et al. 2011).

In emerging market economies such as Vietnam, migration has massively increased over time. After the introduction of the doi moi reforms in the 1980s, a shift was witnessed from organized migration to spontaneous migration. According to Dang et al. (2003), de-collectivization in the agricultural sector increased foreign direct investment flows and liberalization of the economy as part of the reforms provided an initial push to domestic migration. Later on, the growth in the private sector after the Enterprise Law was enacted in 2000, provided more lucrative job opportunities in the urban centers, increased the rural-urban wage gap, and hence promoted further influx from the villages to urban cities (Niimi et al. 2009).

Most empirical studies have tried to capture the costs and benefits of the multifacetted migration phenomenon. They focused on the impact of remittances (Lucas and Stark 1985), the determinants of the decision to migrate, and the effect of this decision on the welfare of rural communities (Nguyen et al. 2008, 2009, 2015). Lipton (1980) argued that the impact of migration depends not only on the transfer of remittances and the number of migrants involved but also on the length of absence. However, studies on the extent and length of rural-urban migration are still lacking.

Obviously, the length and the intensity of migration are seen to be important for the development of both rural and urban places. The duration of migrants living outside of communities directly affects labor supply for rural production. Thus, migrants return to the villages to reduce the labor shortage at harvesting time. A longer absence of migrants, however, makes rural communities change their long-term production strategies moving towards less labor-intensive activities. At the same time, the longer the length of migrant stays, the higher may be the pressure of an overcrowded population on infrastructure, social problems, and environmental pollution in the cities.

Against this background, the migrants in the cities have to decide whether to stay longer in the cities or return to the countryside. This decision not only affects their rural households but also determines the socioeconomic development strategies of both rural and urban authorities. Accordingly, the overall objective of this paper is to identify the length and the intensity of rural-urban migration and to analyze the decision on migration in Vietnam.

The paper is structured as follows: in the next section, a brief review of the literature is presented. In Section 3.1, the database used for the descriptive and econometric analyses is introduced, followed by Section 3.2 that describes the methodology including the econometric models. Section 4 presents the results of the study including the factors that determine whether migrants stay in the cities or return home to the rural areas. Finally, Section 5 concludes. 


\section{Literature review}

The migration literature has focused on determining the decisions of migrants whether to migrate or not and the impact of related remittances on development. However, there are only a few studies on the length of migration. Djajic and Milbourne (1988), Galor and Stark (1990), and Dustmann (1995, 2000) analyzed the importance of migration as part of a lifetime utility maximization plan with given budget (and liquidity) constraints. The decision on whether to migrate or not, as well as the optimal point to return, is considered as the decision of the individual with the purpose to achieve a lifetime utility maximization. Dustmann (2003) added different macro factors to this basic framework. He used data from the German Socio-Economic Panel and a simple dynamic model to determine the optimal migration duration. He found that if migration is temporary, the duration of migration decreases when the economic disparity between the sending region and the receiving region increases. A wage increase in the receiving region will increase the marginal value of the stay (relative wage effect). At the same time, it decreases the marginal utility of wealth since the migration costs such as the living costs at the destination increase. Migrants, on the one hand, would like to remain at their destination as a response to increasing wages; on the other hand, the gain from staying decreases and this has a counteracting effect. Therefore, higher wages in destination areas may have a positive or negative effect on the optimal duration of migration.

Conversely, Borodak and Tichit (2013) found that the expected wage difference between Moldova and destination places (mostly in the EU) had no effect on the duration of migration. Instead, individual characteristics including age and education level were found to have a positive effect on the length of migration. Family ties (migrant as a household head, or the spouse, or having a child at home), however, have a strong negative influence on the duration of the stay of a migrant in the city.

Steiner and Velling (1994) analyzed the expected duration of guest workers staying in Germany. They showed that apart from employment, the expected length of stay is strongly affected by the family context in the host country, e.g., education stage of the children, possessing property at home or abroad, and the amount of remittances delivered to the country of origin. In addition, social networks increase the length of migration, especially through the support and information that are provided on the economic and labor market conditions in the host country (Constant and Massey 2003). This is also supported by the findings of Carrion-Flores (2006) who examined the optimal migration duration of Mexican immigrants in the USA. Furthermore, they found that an expected labor wage increase in the USA acts as a "pull" factor and increases the duration of migration.

In the Asian context, Demurger and $\mathrm{Xu}$ (2013) examined the effect of left-behind children on the length of internal migration, or the optimal migration duration in China, by determining several factors of individual and family and origin hometown characteristics. They found that on the one hand, both economic (having a job at destination) and non-economic (education level and household size) factors have a positive effect on the duration of migration. On the other hand, leaving behind children has a negative impact on the length of stay and the intention of parent migrants to settle in cities.

Kaufmann (2007) developed the concept of migration intensity to capture the extent to which migrants are engaged in the destination area. It is defined as the degree to 
which a migrant shifts his or her attachment, association, and engagement from his or her place of origin to the place of destination. According to Kaufmann (2007), remittance behavior, choice of migration pattern, and localized investment behavior are likely to be correlated; these behaviors also depend on the location of origin or destination of migrants, consequently affecting the intention of migrants to return or stay. Sending remittances to original households may be evidence that migrants remain attached to the origin and that they plan to return home. Similarly, the selected location (original or destination place) of investment regarding physical, human, and social capital would be correlated with the return plan of a migrant (Steiner and Velling 1994; Kaufmann 2007).

In Vietnam, internal migration has played a significant role in its socioeconomic development. Due to the growth of the industrial sector, the demand for labor increased and triggered rural-urban migration. According to the 2009 Census, 6.6 million people migrated internally in Vietnam between 2004 and 2009. Accordingly, there are several studies which aimed at analyzing the determinants and impacts of migration in Vietnam; they find that the majority of migrants move because of economic reasons (e.g., Niimi et al. 2009; UNFPA 2006, 2010; Dang et al. 2003) and that migration helps in reducing poverty and improving the welfare of rural households by increasing their per capita income via remittances (Nguyen et al., 2015). However, to the best of our knowledge, there has been no study that deals with the length of migration and/or migration intensity in Vietnam. This could be partly attributed to the scarcity and quality of data. In fact, most research papers from Vietnam use the General Statistics Office (GSO) data set which is not suitable for studying migration (Pincus and Sender, 2008). The official data sets largely underestimate the actual number of migrants because only the officially registered households being at least 6 months in the survey location are covered, and migrants without a permanent residence status are ignored in the sample. In this paper, the migration duration and intensity in Vietnam are calculated based on a unique data set which is described in the following.

\section{Data and methodology}

\subsection{Data}

The empirical analysis uses data from the project "Vulnerability to poverty: A consequence for development of emerging Southeast Asian countries" (DFG FOR 756) funded by the German Research Foundation. It includes 2200 rural households from Vietnam who had been surveyed in 2007, 2008, and 2010 in Ha Tinh, Thua Thien Hue, and Dak Lak provinces. The data set is unique as it collects comprehensive household level data, including information on household composition and dynamics, occupation, education, income by source, assets, consumption, and several types of shock experiences. The household head or a representative also provides information on migrant household members. Migration information includes the duration that a migrant was absent from his or her original household, the migration destination, and the remittance transfers between migrants and their households. In this study, only adult members are included in the sample. In total, about 7000 individual household members of 10,000 are available for the analysis in each survey wave. 
Simultaneously, a migrant tracking survey of 299 migrants of those rural households was carried out in Ho Chi Minh City and two surrounding provinces, namely Dong Nai and Binh Duong, in 2010. This survey explored the migrants' history, working and living conditions, social integration, remittance transfers between migrant members and their families, and their shock experiences in the cities.

Moreover, a village head survey was carried out in the local communities of the rural households to collect general information about the communities, including geographical situation, physical infrastructure, and demographic characteristics of the community.

To identify the effect of macro level indicators on the length of migration, secondary data such as GDP growth and income gap between the main destination and original provinces were also included in the analysis. This data was taken from the Vietnam GSO (2011) and the World Bank (2016) database.

\subsection{Methodology}

To address the questions about the length and the intensity of migration and their respective determinants, this paper follows two specific steps. In the first step, the length of stay in the city along with the factors that motivate the decision of migrants to stay longer in the cities is identified. In the second step, the Index of Migration Intensity is constructed and its determinants are analyzed. For this purpose, two specific estimation models have been developed.

\subsubsection{Determining the length of migration}

In the literature, most studies on the duration of migration were based on the decision of migrants to return home and the proportional hazards model was then used to identify whether migrants changed their situation to be non-migrants or how long a migrant remained a migrant (Demurger and $\mathrm{Xu}$ 2013; Borodak and Tichit 2013; Carrion-Flores 2006). Migration, especially internal migration, however, is a dynamic activity in which a person could change between a migration and non-migration situation several times a year. Therefore, the proportional hazards model is not suitable for measuring the length of migration.

Moreover, the distribution of the length of migration is a censored variable, in which the length of those who did not participate in migration were all reported as zero (80-90\% of the observations). In addition, migration is a self-selected rather than a randomly assigned process, in which the unobservable variable may affect both the decision of migration and the decision regarding the length of migration. A Tobit regression is developed to deal with the censored dependent variable. Since the study used panel data, a random-effect Tobit model is employed in this study. According to Boman (2011), a Tobit I model with random-effect estimations produces less biased results than Heckit or double hurdle models, or than using instrumental variables. Our model is described as:

$$
y_{i t}^{*}=\beta x_{i t}+v_{i}+\epsilon_{i t}
$$

where $y_{i t}^{*}$ is the latent variable that is observed for values greater than zero, and censored otherwise. The observed $y_{i t}$ is defined by the following measurement equation: 


$$
y_{i t}= \begin{cases}y_{i t}^{*} & \text { if } y_{i t}^{*}>0 \\ 0 & \text { if } y_{i t}^{*}<0\end{cases}
$$

$y_{i t}$ is the length of migration of household members staying outside of their original household in a year and is measured in months. The decision on how long a migrant remains at a destination depends on several factors. Our basic model, model 1, uses independent variables such as individual household members, household characteristics, and village characteristics to determine the length of migration (see Appendix 1, Table 6). This is similar to Demurger and Xu (2013), Borodak and Tichit (2013), and Carrion-Flores (2006). However, since the employment opportunities at destination and original places can lengthen or shorten the duration of migration, we add several indicators of employment opportunity from the World Bank (2016) data set in subsequent models 2-4: in model 2, we add the disparity of income between the main destination and original provinces, in model 3 the share of agricultural production value in total GDP, and in model 4 the growth of GDP per capita at the national level. These macro indicators are included separately in models 2,3 , and 4 as explanatory variables since they are likely to correlate with each other.

\subsubsection{Determining the migration intensity}

Migration intensity cannot be directly observed; however, factors that reflect migration intensity can be used to create the Index of Migration Intensity (IMI). We consider similar factors as Kaufmann (2007) and use the principal component analysis approach to construct the IMI as follows:

$$
Y=a_{1} X_{1}+a_{2} X_{2}+a_{3} X_{3}+a_{4} X_{4}
$$

where $Y$ is the constructed IMI, $a_{i}$ are the principal component coefficients, and $X_{i}$ is a set of variables including the length of migration, remittance transfers, localized physical assets, and localized social capital. The length of migration indicates the average proportion of total time that a migrant spends in the destination in a year. In general, if a migrant spends more time at his or her original place, this indicates that he/she intends to return to the village and the migration intensity is lower than for those spending more time in the destination area. Remittance transfers are defined as the proportion of the income of a migrant remitted to the original household in a village in a year. The localized physical assets indicate whether a migrant owns a house in the place of destination and thus is less likely to return home. The localized social capital is defined as the social integration in the place of destination. It is characterized by the proportion of close friends living in the destination area. It is hypothesized that a migrant with a higher level of social integration is less likely to return home.

In addition, we use the ordinary least squares (OLS) regression to determine the factors affecting the Index of Migration Intensity.

$$
Y=f\left(\mathrm{IND}_{i}, \mathrm{HH}_{j}, \mathrm{Vill}_{k}\right)
$$

where $\mathrm{IND}_{i}$ are the individual characteristics of migrant $i, \mathrm{HH}_{j}$ is the migrant household characteristics $j$, and $V_{i l l}$ refer to the village characteristics $k$. For achieving robust estimated results, a bootstrap technique is used. The descriptive statistics of these variables are presented in Appendix 2, Table 7. 


\section{Results and discussion}

This section presents the results of the study with the first sub-section discussing the determinants of the length of migration and the second one presenting the results on the migration intensity.

\subsection{Determining the length of migration}

Figure 1 describes the length of migration by month in 2007, 2008, and 2010. As can be seen, migration has become an important activity of rural households. The number of migrants increased from 854 migrants in 2007 (12\% of the total sample) to 1323 migrants in 2010 ( $19 \%$ of the total sample). In addition, rural-urban migrants prefer moving out for longer periods. This is indicated by 57,52 , and $62 \%$ of the total migrants in 2007,2008 , and 2010, respectively, who stay between 9 and 12 months in the cities.

Figure 2 shows that the GDP in Vietnam has been increasing, and this could act as a "pull" factor. The growth of GDP per capita reflects economic development and is hypothesized to pull people out of rural areas into urban ones. The GDP per capita in Vietnam has increased from 784 USD in 2007 to 820 USD in 2008 and to 900 USD in 2010. This process is expected to spur further rural-urban migration.

Interestingly, in 2008, the share of the agricultural sector is the driver of GDP growth. As most of the agricultural activities are associated with rural areas, this could represent a growth in income from rural areas. On the one hand, combined with concerns about migration risks in the new places, it could make rural residents become less likely to move out of their village. On the other hand, rural residents with higher incomes who live under poor living conditions, such as low quality of transportation, communication infrastructure, and education and health services, may prefer to migrate out to the cities with better living conditions. Therefore, the effect of this variable is ambiguous.

Finally, Table 1 presents the income disparity ratio between the main destinations (Ho Chi Minh City, Dong Nai and Binh Duong provinces) and the original provinces (Ha Tinh, Thua Thien Hue, and Dak Lak). The absolute figures are presented in Appendix 3, Table 8 . On average, the income disparity is 2.5 times but has slightly

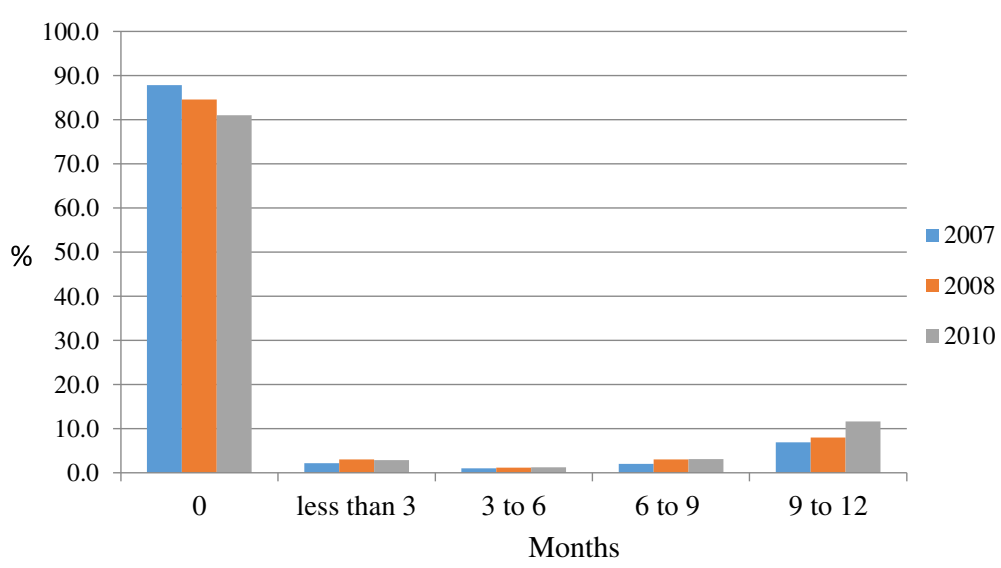

Fig. 1 The length of migration (percent). Source: based on the DFG Rural Household Surveys 2007, 2008, and 2010 


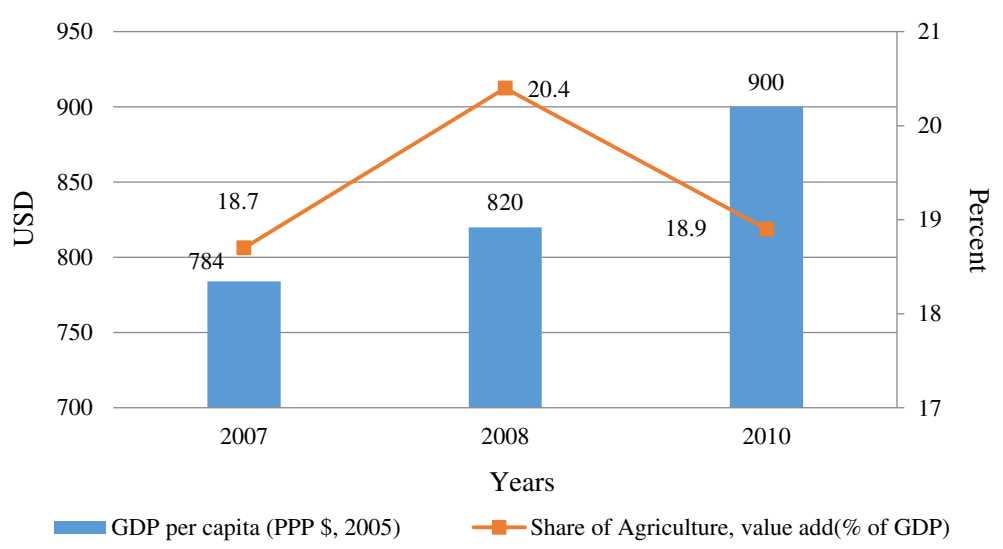

Fig. 2 GDP per capita and share of the agricultural sector in total GDP. Source: World Bank (2016) Data http://data.worldbank.org/indicator/NV.AGR.TOTL.ZS/countries

narrowed down over time. This implies that the growth rate of income in the original provinces is higher than the growth rate of income in destination places. Therefore, it may have positive and negative effects on the length of migration.

The random-effect Tobit regression model estimates of the determinants of the length of migration are presented in Table 2. Model 1 represents individual, household, and village characteristics and provincial dummy variables. The variables "Number of years in school" and "Marital status" are positive and statistically significant; this indicates that single migrants with higher education are more likely to stay longer in the cities. Moreover, the age of a migrant is positively related with the duration of stay. However, the relationship is not linear. The older they are, the less time they spend in the cities, indicated by the negative and statistical significance of the variable "Age squared."

With regard to household characteristics, the variable "Female household head" is negative and statistically significant. Households with female heads account for $13 \%$ of total households, and migrants from these households leave their village for shorter periods than the ones who come from households with a male head. This can be explained by the fact that migrants of female-headed households work outside of their village to support the household income but return home when additional labor is required for activities such as harvesting.

In addition, more educated household heads support their migrants by motivating them to stay longer in the cities with the expectation of improving knowledge and

Table 1 Disparity of income of main destinations and original provinces

\begin{tabular}{llll}
\hline Original provinces & 2006 & 2008 & 2010 \\
\hline Ha Tinh & 2.97 & 3.05 & 2.86 \\
Thua Thien Hue & 2.30 & 2.26 & 2.27 \\
Dak Lak & 2.34 & 2.31 & 2.25 \\
Average & 2.54 & 2.54 & 2.46 \\
\hline
\end{tabular}

Note: since VHLSS was not conducted in 2007, this study depends on data from 2006 for this year Source: Vietnam General Statistics Office. http://www.gso.gov.vn/default.aspx?tabid=417\&idmid=4\&ltemID=12428 
Table 2 Random-effect Tobit regression

\begin{tabular}{|c|c|c|c|c|}
\hline & $\begin{array}{l}\text { Model } 1 \\
\text { coef/se }\end{array}$ & $\begin{array}{l}\text { Model } 2 \\
\text { coef/se }\end{array}$ & $\begin{array}{l}\text { Model } 3 \\
\text { coef/se }\end{array}$ & $\begin{array}{l}\text { Model } 4 \\
\text { coef/se }\end{array}$ \\
\hline \multicolumn{5}{|l|}{ Individual characteristics } \\
\hline \multirow[t]{2}{*}{ Female (1 yes, 0 no) } & 0.113 & 0.089 & 0.117 & 0.056 \\
\hline & $(0.357)$ & $(0.356)$ & $(0.357)$ & $(0.356)$ \\
\hline \multirow[t]{2}{*}{ Number of years in school } & $0.599^{* * *}$ & $0.588^{* * *}$ & $0.603^{* * *}$ & $0.578^{* * *}$ \\
\hline & $(0.045)$ & $(0.045)$ & $(0.045)$ & $(0.045)$ \\
\hline \multirow[t]{2}{*}{ Marital status (1 single, 0 others) } & $6.584^{* * *}$ & $6.592^{* * *}$ & $6.487^{* * *}$ & $6.549 * * *$ \\
\hline & $(0.463)$ & $(0.461)$ & $(0.464)$ & $(0.460)$ \\
\hline \multirow[t]{2}{*}{ Age (years) } & $1.746^{* * *}$ & $1.693^{* * *}$ & $1.752^{* * *}$ & $1.610^{* * *}$ \\
\hline & $(0.094)$ & $(0.094)$ & $(0.094)$ & $(0.094)$ \\
\hline \multirow[t]{2}{*}{ Square of age } & $-0.028^{* * *}$ & $-0.027^{* * *}$ & $-0.028^{* * *}$ & $-0.026^{* * *}$ \\
\hline & $(0.001)$ & $(0.001)$ & $(0.001)$ & $(0.001)$ \\
\hline \multicolumn{5}{|l|}{ Household characteristics } \\
\hline \multirow[t]{2}{*}{ Female head (1 yes, 0 no) } & $-0.920^{*}$ & $-0.866^{*}$ & $-0.934^{*}$ & $-0.895^{*}$ \\
\hline & $(0.514)$ & $(0.513)$ & $(0.514)$ & $(0.511)$ \\
\hline \multirow[t]{2}{*}{ Number of years in school of $\mathrm{HH}$ head (years) } & $0.113^{* *}$ & $0.109^{* *}$ & $0.110^{* *}$ & $0.094^{*}$ \\
\hline & $(0.051)$ & $(0.050)$ & $(0.051)$ & $(0.050)$ \\
\hline \multirow[t]{2}{*}{ Age of HH head (years) } & $0.277^{* * *}$ & $0.264^{* * *}$ & $0.276^{* * *}$ & $0.243^{* * *}$ \\
\hline & $(0.018)$ & $(0.018)$ & $(0.018)$ & $(0.018)$ \\
\hline \multirow[t]{2}{*}{ Dependency ratio } & $-8.158^{* * *}$ & $-8.485^{* * *}$ & $-8.674^{* * *}$ & $-9.484^{* * *}$ \\
\hline & $(0.909)$ & $(0.908)$ & $(0.935)$ & $(0.915)$ \\
\hline \multirow[t]{2}{*}{$\mathrm{HH}$ engaged in non-farm activities ( 1 yes, 0 no) } & $0.666^{*}$ & 0.538 & $0.684^{* *}$ & 0.380 \\
\hline & $(0.340)$ & $(0.339)$ & $(0.340)$ & $(0.339)$ \\
\hline \multirow[t]{2}{*}{ Total own land (ha) } & -0.084 & -0.079 & -0.087 & -0.109 \\
\hline & $(0.082)$ & $(0.081)$ & $(0.083)$ & $(0.084)$ \\
\hline \multirow[t]{2}{*}{ Total number of demographic shocks } & $0.396^{* *}$ & 0.194 & $0.513^{* *}$ & 0.204 \\
\hline & $(0.198)$ & $(0.199)$ & $(0.203)$ & $(0.197)$ \\
\hline \multirow[t]{2}{*}{ Total number of social shocks } & $1.179^{* *}$ & 0.675 & $1.277^{* *}$ & 0.049 \\
\hline & $(0.527)$ & $(0.529)$ & $(0.529)$ & $(0.531)$ \\
\hline \multirow[t]{2}{*}{ Total number of agricultural shocks } & $-0.489^{* * *}$ & $-0.673^{* * *}$ & $-0.351^{* *}$ & $-0.709^{* * *}$ \\
\hline & $(0.150)$ & $(0.152)$ & $(0.160)$ & $(0.150)$ \\
\hline \multirow[t]{2}{*}{ Total number of economics shocks } & 0.346 & 0.140 & 0.440 & 0.172 \\
\hline & $(0.438)$ & $(0.437)$ & $(0.439)$ & $(0.434)$ \\
\hline \multicolumn{5}{|l|}{ Village characteristics } \\
\hline \multirow[t]{2}{*}{ Number of enterprises } & -0.102 & -0.092 & -0.101 & -0.078 \\
\hline & $(0.091)$ & $(0.091)$ & $(0.091)$ & $(0.091)$ \\
\hline \multirow[t]{2}{*}{ Access to the Internet (\% of households) } & $0.074^{* * *}$ & $0.061^{* * *}$ & $0.079^{* * *}$ & 0.023 \\
\hline & $(0.023)$ & $(0.023)$ & $(0.023)$ & $(0.024)$ \\
\hline \multirow[t]{2}{*}{ Log of distance to district town } & -0.168 & -0.080 & -0.175 & -0.057 \\
\hline & $(0.210)$ & $(0.209)$ & $(0.210)$ & $(0.209)$ \\
\hline \multirow[t]{2}{*}{ Ha Tinh province (1 yes, 0 no) } & $3.052^{* * *}$ & $14.439^{* * *}$ & $3.081^{* * *}$ & $3.092^{* * *}$ \\
\hline & $(0.466)$ & $(1.554)$ & $(0.466)$ & $(0.465)$ \\
\hline \multirow[t]{2}{*}{ Thua Thien Hue province ( 1 yes, 0 no) } & $3.511^{* * *}$ & $3.077^{* * *}$ & $3.563^{* * *}$ & $3.576^{* * *}$ \\
\hline & $(0.454)$ & $(0.455)$ & $(0.454)$ & $(0.452)$ \\
\hline
\end{tabular}


Table 2 Random-effect Tobit regression (Continued)

\begin{tabular}{|c|c|c|c|c|}
\hline \multicolumn{5}{|l|}{ Macro indicators } \\
\hline \multirow[t]{2}{*}{ Income gap between destination and original provinces } & & \multicolumn{3}{|l|}{$-17.402^{* * *}$} \\
\hline & & $(2.266)$ & & \\
\hline \multirow[t]{2}{*}{ Share of agricultural production in total GDP } & & & \multicolumn{2}{|l|}{$0.422^{* *}$} \\
\hline & & & $(0.173)$ & \\
\hline \multirow[t]{2}{*}{ Growth of GDP per capita } & & & & $25.645^{* * *}$ \\
\hline & & & & $(2.126)$ \\
\hline \multirow[t]{2}{*}{ Constant } & $-59.197^{* * *}$ & $-17.372^{* * *}$ & $-67.365^{* * *}$ & $-227.072^{* * *}$ \\
\hline & $(1.983)$ & $(5.694)$ & $(3.924)$ & $(14.219)$ \\
\hline Number of observations & 21,045 & 21,045 & 21,045 & 21,045 \\
\hline
\end{tabular}

Source: own calculations based on the DFG Rural Household Surveys 2007, 2008, and 2010

$*^{* *}$, and ${ }^{* * *}$ indicate statistically significant levels at 10,5 , and $1 \%$, respectively

achieving a better quality of life. The higher the age of the household head, the longer the migrant tends to stay in the cities. However, a higher dependency ratio significantly reduces the length of migration. This result is consistent with Demurger and Xu (2013), namely the higher the number of elderly and children in the original households, the shorter the length of migration.

Also, migrants of households who engage in non-farm activities tend to stay longer in the cities. Engaging in non-farm activities makes household members familiar with non-farm jobs, which are popular in the cities. Migrants could then find a better job and improve their living conditions and, therefore, prefer to stay longer in the cities. Also, non-farm households do not require as much manual labor. Therefore, the migrant need not return home as frequently. At the same time, the variable "Total own land," which refers to agricultural production, has the expected negative sign but is statistically insignificant. Agricultural production is considered as a labor-intensive activity; therefore, the more land a household has, the more labor is required which could shorten the length of migration.

The types of shocks considered in the model are demographic shocks that refer to illness or death of a household member or social shocks such as theft or conflict with neighbors in the village. Agricultural shocks such as floods, droughts, crop pests, or livestock diseases and economic shocks that relate to job loss, collapse of business, strong increase of input prices, or strong decrease of output prices are also included. Households that experienced a higher number of demographic and social shocks make their migrant members stay longer in the cities, while households that experienced a higher number of agricultural shocks reduce the length of absence of their migrant members. In general, it can be said that idiosyncratic shocks of rural households such as illness (demographic shocks) or social insecurity (social shocks) positively affect the duration of migrants' stay in the cities. In contrast, covariate shocks, such as weather damages, or crop and livestock epidemics shorten the length of stay of migrants in the cities. In case of agricultural shocks, the rural households may require more labor force and hence forcing the migrant to return home in order to allow the household to recover.

In terms of village characteristics, the variable "Access to the Internet" is positive and statistically significant, which indicates that better communication infrastructure in the 
village could improve the capacity of communication of rural households and their migrants in the cities. This makes migrants willing to increase their length of migration.

Finally, migration is more likely to occur in Ha Tinh and Thua Thien Hue provinces (Nguyen et al., 2015), and the duration of migration of these migrants is more likely longer than the duration of migration of migrants from Dak Lak province. Since Dak Lak province is located in the High Land region where job opportunities are plenty in coffee and wooden processing sectors, rural residents are less likely to out-migrate to find a job and migrants also have to return home for taking care their household's business. Ha Tinh and Thua Thien Hue provinces (located in the Central Coast region) are characterized by small-scale agricultural production and scarce non-farm job opportunities, making migrants stay longer in the cities to earn money (UNFPA 2010).

In model 2, the income gap between destination and original provinces is included as a macro indicator in the model. Consistent with Dustmann (2003), this indicator is negative and statistically significant. Since migrants are considered to be a low-income group in the cities (UNFPA 2010), the increase in their income also leads to increasing living cost. Therefore, they are more likely to shorten their lengths of migration to reduce cost. The negative sign and significance of this variable can also explain that the narrowing income gap between destination and original provinces increases the length of migration. The narrowing of the income gap resulted from the higher income growth in original provinces in comparison to the growth of income in destination places.

This argument is supported by model 3, where the variable "Share of agricultural production in total GDP" is positive and statistically significant. As agricultural production occurs and this increase in total GDP reflects increasing income in the rural areas, the length of migration increases. This result is not in resonance with general expectations and once again stresses on the ambiguity of this variable. Finally, in model 4, as expected, economic growth at the national level is indicated by the growth of GDP per capita, and this causes an increase in the length of migration.

\subsection{Migration intensity}

In this section, we first focus on descriptive statistics and discuss the subjective return plan of migrants and their households' expectations of living places for their children in the future. This is followed by the results on the migration intensity and its determinants.

Table 3 is divided into two parts. Part a presents the subjective return plans of migrants in the cities, and part b shows the households' expectations of living places for their children in the future. While $64 \%$ of the migrants wish to return to their home village, only $16 \%$ would prefer to stay back in the cities. This is interesting because only $36 \%$ of the rural households expect that their migrant member(s) will return back in the future. A bigger proportion of the rural households believe that their migrants would either stay back in the cities $(26 \%)$ or move to other provincial cities $(38 \%)$. The results highlight the inconsistencies between migrants' and households' expectations on the future destinations of migrants. Despite the fact that living in large cities such as Ho Chi Minh City or its surrounding provinces may provide opportunities to ruralurban migrants to improve their living conditions, they may wish to return in the 
Table 3 Subjective plan of future location of migrants and their households

\begin{tabular}{ll}
\hline a. Migrant's plan to return to the home village & Number of migrants (\%) \\
Plan & $155(64)$ \\
Yes & $48(20)$ \\
Undecided & $40(16)$ \\
No & \\
b. Household's expectation of where the migrant would return & Number of households (\%) \\
Final destination & $87(36)$ \\
Village & $93(38)$ \\
Provincial cities & $63(26)$ \\
HCMC/Hanoi & \\
\hline
\end{tabular}

Source: own calculations based on the DFG Migrant Survey in 2010

longer run to be close to their families. At the same time, they may also face unpredictable events in the cities that make them more vulnerable (Le et al. 2011), increasing their wish to return to their home villages. However, the instability of rural household livelihoods and the lack of job opportunities make rural villages not an ideal place for their children to stay. Therefore, rural households do not expect their migrant members to return home, however, would like them to stay close by. Thus, the plan to live in the provincial city becomes a reasonable solution for both migrants and their households.

Table 4 shows the results on the migration intensity. The four groups represent quartiles created using the index. The higher the index, the lower are the chances of the migrant to return back to his or her place of origin. Accordingly, the first group with the lowest IMI reflects migrants who are more likely to return to their home village, while the fourth group with the highest IMI includes migrants who are less likely to return to their home village, rather intending to stay in the cities in the long run. The majority of migrants have an IMI between 0.25 and 0.5 , indicating that they feel quite attached to their home villages.

The results are also in line with the various selected indicators (Table 4). The share of time in the cities is shortest for the group with the lowest IMI while migrants with the highest IMI spend their time mostly in the cities. Migrants from the first group also send larger shares of their income to their rural households and do not own any property in the city. In contrast, migrants from the fourth group do not send any remittances and

Table 4 Index of Migration Intensity

\begin{tabular}{llllll}
\hline Groups & \multicolumn{2}{l}{ Quartiles } & & \\
\cline { 2 - 5 } & 1 & 2 & 3 & 4 & Average \\
\hline Share of time in the cities & 0.928 & 0.999 & 0.999 & 1.000 & 0.981 \\
Social integration in the cities & 0.179 & 0.058 & 0.330 & 0.790 & 0.269 \\
Share of remittances & 0.022 & 0.001 & 0.000 & 0.000 & 0.006 \\
Own house in the cities & 0.000 & 0.000 & 0.000 & 0.153 & 0.030 \\
Average score & -1.53 & 0.290 & 0.505 & 0.984 & \\
Number of migrants & 70 & 150 & 25 & 43 & \\
\hline
\end{tabular}

Source: own calculations based on the DFG Migrant Survey in 2010 
own property in the cities. The variable "Social integration in the cities" illustrates the same trend, meaning that the higher the IMI, the higher the social integration of migrants in the cities; however, this is not as clear for the first group since they seem to do slightly better with respect to their social integration than migrants from the second group. This could be possible because migrants might have followed their friends and relatives who welcome and help them at the beginning of their stay in the cities.

The results on the determinants of migration intensity are shown in Table 5. Migrant characteristics such as the number of years in school or experiences with shocks in the cities are statistically significant. The positive sign of the variable "Number of years in school" indicates that migrants with higher education are more likely to stay permanently in the cities and hence increase the migration intensity. This result is not surprising as more educated migrants can find better jobs with higher salaries and better working conditions. This enables them to achieve better living conditions. They prefer to stay in the cities instead of returning home where less job opportunities and vulnerable living conditions exist. In contrast, "Experienced shocks in the cities" negatively impacts migration intensity. This implies that experiencing more shocks in the cities

Table 5 Determinants of migration intensity (OLS regression)

\begin{tabular}{|c|c|c|}
\hline & Coef & Se \\
\hline \multicolumn{3}{|l|}{ Migrant characteristics } \\
\hline Female migrant (1 yes, 0 no) & -0.052 & 0.191 \\
\hline Marital status ( 1 single, 0 others) & -0.120 & 0.239 \\
\hline Age (years) & 0.161 & 0.131 \\
\hline Age squared & -0.002 & 0.003 \\
\hline Number of years in school (years) & $0.053^{* *}$ & 0.027 \\
\hline Government support (1 yes, 0 no) & 0.292 & 0.272 \\
\hline Experienced to shocks in the cities ( 1 yes, 0 no) & $-0.334^{*}$ & 0.185 \\
\hline \multicolumn{3}{|l|}{ Household characteristics } \\
\hline Female household head (1 yes, 0 no) & 0.164 & 0.265 \\
\hline Log of total land own (ha) & -0.048 & 0.118 \\
\hline Total household members & $0.087^{*}$ & 0.049 \\
\hline Household participated on non-farm activities ( 1 yes, 0 no) & -0.008 & 0.172 \\
\hline \multicolumn{3}{|l|}{ Village characteristics } \\
\hline Access to public water supply (\% households in village) & -0.001 & 0.002 \\
\hline Access to the Internet (\% households in village) & $-0.011^{*}$ & 0.007 \\
\hline Number of enterprises & $0.188^{*}$ & 0.106 \\
\hline Number of social problems & 0.139 & 0.120 \\
\hline Constants & $-3.470^{*}$ & 1.811 \\
\hline Number of observations & 243 & \\
\hline Replications & 1000 & \\
\hline Wald $\operatorname{chi}^{2}(1)$ & 32.25 & \\
\hline Prob $>c h i^{2}$ & 0.006 & \\
\hline$R$-squared & 0.1068 & \\
\hline
\end{tabular}

Source: own calculations based on the DFG Rural Household Surveys and DFG Migrant Survey in 2010

${ }^{*}$ and ${ }^{* *}$ indicate statistically significant levels at 10 and 5\%, respectively. The independent variable is the Index of Migration Intensity 
makes it less likely that the migrant will settle in the cities or they are more likely to return to their home village, since it is too risky for them to stay longer in the cities, especially in case the government support is not working well.

In contrast to Kaufmann (2007), the variable "Total household members" is positive and statistically significant, implying that migrants from households with a higher number of members tend to stay longer in the cities. A high number of household members characterized by small-scale cultivated land motivate the re-allocation of rural citizens; therefore, migrants might not intend to return to their home village.

With regard to the village characteristics, the variable "Access to the Internet" is negative and statistically significant. This can be explained by the fact that access to the Internet improves the possibility of communication with the migrants. Access to information could also reduce the migration intensity or make migrants more likely to return to their home village. It can be said that improving the living conditions in the villages motivates migrants to return in the future. This argument is slightly supported by the positive sign of the variable "Access to public water" though it is statistically insignificant.

The variable "Number of enterprises" is positive and statistically significant which indicates that the higher the number of enterprises in the village, the higher the migration intensity or migrants' intention to stay in the cities. This sounds like an unlikely result. However, an increase in the number of enterprises could provide rural households in the village a chance to improve their income, thus, causing migrants not to send any remittances. These migrants can focus on improving their living conditions in the cities. Therefore, improving living conditions is more important than providing job opportunities to attract migrants to return to their home villages. This is also in resonance with our finding that with an increase in the income gap between the origin and destination places, the duration of migration increases.

\section{Conclusions}

This paper aims at identifying the determinants of the length and intensity of migration of rural household members within Vietnam. First, a random-effect Tobit regression model is used to analyze panel data of 2200 rural households in Vietnam from 2007, 2008, and 2010 to determine the factors affecting the number of months that rural-urban migrants live outside of their village. Second, a Migration Intensity Index is constructed using the principal component analysis with data from 299 migrants being affiliated to the rural households but living in the cities. Finally, an OLS regression is run to identify the determinants of the migration intensity.

The empirical evidence from the random-effect Tobit regression suggests that single migrants with higher education tend to stay longer in the cities. In addition, household characteristics such as the education level of the household head and household engagement in non-farm activities also increase the length of migration. Thus, providing better job opportunities and improving infrastructure in the rural areas would help to partly reverse the trend of rural-urban migration. This would also release the pressure on the cities to improve the existing infrastructure and expand 
urban services such as housing or education. However, households with female heads and with higher number of elders and/or children do not support the choice of migrants to remain longer in the cities. This points to the fact that rural households depend on the workforce and support of their migrant members especially in times as harvesting. Improved management and organization of farming activities in the rural areas through cooperatives, e.g., may help to ease the pressure during high-season activities. In addition, social security programs supporting the elderly and disadvantaged and single parent groups in the rural areas generally takes off the pressure from migrants to have to return to their places of origin in certain times of the year.

The length of migration is likely to be longer for households experiencing idiosyncratic shocks as illness or personal reasons, and social insecurity in the communities. However, covariate shocks such as weather damage, or crop and livestock epidemics, shorten the length of their stays in the cities. Migration is thus considered more as a longer-term risk-coping strategy in case of idiosyncratic shocks. Covariate shocks are responsible for migrants to return home, probably to support the livelihood activities of their rural households with their labor force. Financial relief support programs by the government or private donors in case of shocks tend to help in these situations.

In general, migrants tend to stay longer in the cities if their villages have Internet access and if they are from $\mathrm{Ha}$ Tinh and Thua Thien Hue provinces where the job opportunities are scarce. Thus, better job opportunities in the rural areas would reverse the trend of rural-urban migration, while providing information and communication services such as the Internet to the rural households would promote rural-urban migration since the families have the chance to stay in contact.

Finally, the evidence of macro indicators show that the national economic growth and the narrow income gap between destination and original places indicated by the higher growth rate of income of the original provinces (in comparison to the growth rate of the destination places) increases the time of stay in the cities.

The results on the migration intensity indicate that most migrants plan to return home in the future. However, their rural households do not necessarily expect their migrant members to return home in the future but rather expect them to be based in provincial cities close by. This reflects the wish of parents to see their children to have a higher living standard with better job opportunities on the one hand and to have them living close by on the other hand. This calls for the need to improve job opportunities especially in the provincial cities, again a measure which takes off the population pressure from big cities. At the same time, an increase in job opportunities in the rural areas would also help the rural households to diversify their incomes and improve their own living conditions. Their migrant members would be able to focus on improving their own living conditions in the cities instead of transferring part of their income as remittances to their rural households. And moreover, migrants would be motivated to return to the villages in the longer run. Further research needs to focus on the question of how to develop attractive employment opportunities for the younger and often better educated young generation in the rural and semi-urban areas. 


\section{Appendix 1}

Table 6 Summary statistics of independent variables of the random-effect Tobit regression model

\begin{tabular}{|c|c|c|c|c|c|}
\hline Variables & Obs & Mean & Std. dev. & Min & $\operatorname{Max}$ \\
\hline \multicolumn{6}{|l|}{ Individual characteristics } \\
\hline Female ( 1 yes, 0 no) & 21,045 & 0.50 & 0.50 & 0 & 1.00 \\
\hline Number of years in school & 21,045 & 7.90 & 4.06 & 0 & 20 \\
\hline Marital status ( 1 single, 0 others) & 21,045 & 0.42 & 0.49 & 0 & 1.00 \\
\hline Age (years) & 21,045 & 30.20 & 13.38 & 11 & 64 \\
\hline Square of age & 21,045 & 1090 & 905.4 & 121 & 4096 \\
\hline \multicolumn{6}{|l|}{ Household characteristics } \\
\hline Female head ( 1 yes, 0 no) & 21,045 & 0.13 & 0.33 & 0 & 1.00 \\
\hline Age of HH head (years) & 21,045 & 48.55 & 10.76 & 20 & 99 \\
\hline Numbers of years in school of $\mathrm{HH}$ head & 21,045 & 6.87 & 3.99 & 0 & 20 \\
\hline Dependency ratio & 21,045 & 0.22 & 0.20 & 0 & 0.8 \\
\hline $\mathrm{HH}$ participated in non-farm activities (1 yes, 0 no) & 21,045 & 0.28 & 0.45 & 0 & 1.00 \\
\hline Total own land (ha) & 21,045 & 0.95 & 2.53 & 0 & 62.22 \\
\hline Total number of demographic shocks & 21,045 & 0.41 & 0.67 & 0 & 6.00 \\
\hline Total number of social shocks & 21,045 & 0.06 & 0.24 & 0 & 2.00 \\
\hline Total number of agricultural shocks & 21,045 & 0.74 & 0.91 & 0 & 6.00 \\
\hline Total number of economics shocks & 21,045 & 0.06 & 0.31 & 0 & 3.00 \\
\hline \multicolumn{6}{|l|}{ Village characteristics } \\
\hline Number of enterprises & 21,045 & 0.18 & 1.77 & 0 & 30 \\
\hline Access to the Internet (\% of households) & 21,045 & 0.98 & 5.01 & 0 & 100 \\
\hline Log of distance to district town & 21,045 & 2.31 & 0.82 & -1.61 & 4.32 \\
\hline Ha Tinh province (1 yes, 0 no) & 21,045 & 0.31 & 0.46 & 0 & 1.00 \\
\hline Thua Thien Hue province ( 1 yes, 0 no) & 21,045 & 0.33 & 0.47 & 0 & 1.00 \\
\hline Dak Lak province (1 yes, 0 no) & 21,045 & 0.37 & 0.48 & 0 & 1.00 \\
\hline
\end{tabular}

Source: own calculations based on the pooled data of DFG Rural Household Surveys 2007, 2008, and 2010 


\section{Appendix 2}

Table 7 Summary statistics of independent variables of OLS regression

\begin{tabular}{llllll}
\hline Variables & Obs & Mean & Std. dev. & Min & Max \\
\hline Migration intensity & 243 & -0.09 & 1.27 & -8.92 & 1.98 \\
Migrant characteristics & & & & & \\
Female migrant (1 yes,0 no) & 243 & 0.53 & 0.50 & 0.00 & 1.00 \\
Marital status (1 single, 0 others) & 243 & 0.78 & 0.41 & 0.00 & 1.00 \\
Age (years) & 243 & 24.40 & 5.33 & 15.00 & 47.00 \\
Age squared & 243 & 623.58 & 291.46 & 196 & 2209 \\
Number of years in school (years) & 243 & 10.62 & 3.75 & 2.00 & 19.00 \\
Government support (1 yes, 0 no) & 243 & 0.05 & 0.23 & 0.00 & 1.00 \\
Experienced to shocks in the cities (1 yes, 0 no) & 243 & 0.42 & 0.49 & 0.00 & 1.00 \\
Household characteristics & & & & & \\
Female household head (1 yes, 0 no) & 243 & 0.16 & 0.36 & 0.00 & 1.00 \\
Total land own (ha) & 243 & 0.74 & 1.14 & 0.00 & 12.05 \\
Total household members & 243 & 6.43 & 1.65 & 2.00 & 11.00 \\
Household participated on non-farm activities (1 yes, 0 no) & 243 & 0.63 & 0.48 & 0.00 & 1.00 \\
Village characteristics & & & & & \\
Access to public water supply (\% households in village) & 243 & 32.97 & 40.93 & 0.00 & 100 \\
Access to the Internet (\% households in village) & 243 & 3.50 & 10.93 & 0.00 & 100 \\
Number of enterprises in the village & 243 & 0.13 & 0.54 & 0.00 & 5.00 \\
Number of social problems in the village & 243 & 0.42 & 0.68 & 0.00 & 3.00 \\
\hline
\end{tabular}

Source: own calculations based on the DFG Rural Household Surveys and DFG Migrant Survey in 2010

\section{Appendix 3}

Table 8 Income per capita of selected destination and original provinces (thousand VND per month)

\begin{tabular}{llll}
\hline & 2006 & 2008 & 2010 \\
\hline Destination provinces & & & \\
Ho Chi Minh City & 1480 & 2192 & 3653 \\
Dong Nai & 867 & 1318 & 1763 \\
Binh Duong & 1215 & 1929 & 2698 \\
Original provinces & & & 840 \\
Ha Tinh & 400 & 595 & 1058 \\
Thua Thien Hue & 517 & 804 & 1068 \\
Dak Lak & 507 & 785 & \\
\hline
\end{tabular}

Source: Vietnamese General Statistics Office. http://www.gso.gov.vn/default.aspx?tabid=417\&idmid=4\&ltemID=12428

Abbreviations

DFG: German Research Foundation; GDP: Gross Domestic Product; GSO: General Statistics Office; IMI: Index of Migration Intensity; OLS: Ordinary Least Squares; UNFPA: United Nations Population Fund; USD: US Dollars

\section{Acknowledgements}

The data used in this paper was made available from the project "Vulnerability to Poverty: A consequence for development of emerging Southeast Asian countries" (DFG FOR 756: https://www.vulnerability-asia.uni-hannover.de/ overview.html). We would like to thank the anonymous reviewer and the editor for the useful comments on our paper.

Responsible editor: Denis Fougère 


\section{Funding}

Financial support has been provided for the salaries of Dr. Nguyen and Ms. Sharma by the German Research Foundation (DFG).

\section{Competing interests}

The IZA Journal of Development and Migration is committed to the IZA Guiding Principles of Research Integrity. The authors declare that they have observed these principles.

\section{Author details}

'Institute for Environmental Economics and World Trade, Leibniz University Hannover Königsworther Platz 1, 30167 Hannover, Germany. Institute of Policy and Strategy for Agriculture and Rural Development, 10th Floor, No.12 Vo Van Kiet St, Nguyen Thai Binh Ward, District 1, Ho Chi Minh City, Vietnam.

\section{Received: 11 August 2016 Accepted: 2 November 2016}

Published online: 11 May 2017

\section{References}

Boman A. Does migration pay? Earnings effects of geographic mobility following job displacement. J Popul Econ. 2011;24:1369-84.

Borodak D, Tichit A. Should we stay or should we go? Irregular migration and duration of stay: the case of Moldovan migrants. Migration studies. 2013. p. 1-33.

Carrion-Flores CE. What makes you go back home? Determinants of the duration of migration of Mexican immigrants in the United States. Cambridge: Society of Labor Economists Annual Meeting; 2006.

Constant A, Massey DS. Self-selection, earnings, and out-migration: a longitudinal study of immigrants to Germany. J Popul Econ. 2003;16:631-53.

Dang NA, Tacolli C, Thanh XH. Migration in Vietnam: a review of information on current trends and patterns, and their policy implications. Department for International Development, UK; 2003. URL: http:/www.eldis.org/vfile/upload/1/ document/0903/Dhaka_CP_7.pdf. Accessed 10 July 2016.

Demurger S, Xu H. Left-behind children and return decisions of rural migrants in China. IZA Discussion Paper No. 7727; 2013. URL: http://ssm.com/abstract=2363214. Accessed 10 July 2016.

Dercon S. Income risk, coping strategies and safety nets. Discussion paper, 22. Helsinki: World Institute for Development Economics Research, United Nations University (UNU-WIDER); 2002.

Djajic S, Milbourne R. A general equilibrium model of guest-worker migration: a source-country perspective. J Int Econ. 1988;25:335-51.

Dustmann C. Savings behavior of migrant workers: a life-cycle analysis. Zeitschrift fuer Wirtschafts- und Sozialwissenschaften. 1995;115:511-33.

Dustmann C. Temporary migration and economic assimilation. Swedish Economic Policy Review. 2000;7:213-44.

Dustmann C. Return migration, wage differentials and the optimal migration duration. Eur Econ Rev. 2003:47:353-69.

Galor O, Stark O. Migrants' savings, the probability of return migration and migrants' performance. Int Econ Rev. 1990;31(2):463-7.

General Statistics Office (GSO). Results of the Vietnamese Household Standard Survey 2010; 2011 http://www.gso.gov. vn/default.aspx?tabid=417\&idmid=4\&ltemID=12428. Accessed 10 July 2016.

Kaufmann F. Emigrant or sojourner? Migration intensity and its determinants. PERI Working Papers Series 154, University of Massachusetts Amherst; 2007. http://scholarworks.umass.edu/cgi/viewcontent.cgi?article= 1125\&context=peri_workingpapers. Accessed 10 July 2016.

Le BD, Tran GL, Nguyen TTP. Social protection for rural-urban migrants in Vietnam: current situation, challenges and ppportunities. Research report 08. Sussex: Centre for Social Protection, Institute of Development Studies; 2011.

Lipton M. Migration from rural areas of poor countries: The impact on rural productivity and income distribution. World Dev. 1980:8(1):1-24.

Lucas R, Stark O. Motivations to remit. J Polit Econ. 1985;93:901-18.

Nguyen NP, Tran NTMT, Nguyen TN, Oostendorp R. Determinants and impacts of migration in Vietnam. Working paper 01, Development and Policies Research Center (DEPOCEN); 2008 URL: http://depocenwp.org/upload/pubs/ TranNgoMinhTam/Determinants\%20and\%20Impacts\%20of\%20Migration\%20in\%20Vietnam_DEPOCENWP.pdf. Accessed 03 Aug 2016.

Nguyen VC, Den Berg MV, Lensink R. The impact of working migration and non-working migration on household welfare, poverty and inequality: new evidence from Vietnam. Asia-Pacific Development Journal. 2009;16:59-92.

Nguyen LD, Raabe K, Grote U. Rural-urban migration, household vulnerability, and welfare in Vietnam. World Dev. 2015;71:79-93.

Niimi Y, Pham TH, Reilly B. Determinants of remittances: recent evidence using data on internal migrants in Vietnam. Asian Economic Journal. 2009;23:19-39.

Pincus J, Sender J. Quantifying poverty in Vietnam: Who Counts?. J Vietnamese Stud. 2008;3(1):114-50.

Stark O, Bloom DE. The new economics of labor migration. Am Econ Rev. 1985;75(2):173-8.

Steiner V, Velling J. Remigration behaviour and expected duration of stay of guest workers in Germany. In: Steinmann G, Ulrich RE, editors. The economic consequences of immigration to Germany. Heidelberg: Physica-publisher; 1994.

United Nations Population Fund (UNFPA). Internal migration and related life course events. 2006. http://vietnam.unfpa. org/publications/internal-migration-and-related-life-course-events. Accessed 13 Oct 2016.

United Nations Population Fund (UNFPA). Internal migration: opportunities, challenges and social-economic development in Vietnam. The United Nations Population Fund in Viet Nam; 2010. URL: http://www.un.org.vn/en/ component/docman/doc_details/173-internal-migration-opportunities-and-challenges-for-socio-economicdevelopment-in-viet-nam.html. Accessed 13 Oct 2016.

World Bank, World Bank data, Washington DC, http://data.worldbank.org/indicator/NV.AGR.TOTL.ZS/countries. Accessed 5 June 2016. 